\title{
Paradigm Shift in UN Peacekeeping in the Post Cold War Era
}

\author{
Dr. Amit Mishra \\ Assistant Professor in Political Science, \\ Central University of Tibetan Studies, Sarnath, India
}

\section{Doi:10.5901/mjss.2013.v4n9p109}

\section{Abstract}

UN has carried out 67 peacekeeping operations since 1948. Surprisingly, 54 of them have taken place since 1988. As international relations are dominated by Great Powers to analyse their attitudes through peacekeeping after 1990, it can be clearly seen how realpolitik still shapes the political world. Peacekeeping was adopted during the Cold War as a substitute for collective security and in response to the stalemate between the Permanent Members of the Security Council. In practice, UN peace operations have developed as ad hoc responses to particular crises. Therefore the key concepts of traditional peacekeeping (consent, impartiality, minimum use of force) are often interpreted differently in different missions, broadening the way in which the international community understands what a threat to international peace is. Andersson (2000) asserts that the increasing number of peacekeeping operations after 1990 was due to a change from realpolitik to idealpolitik. UN Secretary-General Boutros-Ghali reflected in his document Agenda for Peace the same universalist and communitarian approach; and has declared the commitment to the primacy of values over interests in the international community. The egoistic passions and self-interests of Great Powers who are the permanent members of Security Council have motivated the increasing number of UN peacekeeping operations after 1990.

The proposed paper will try to explore such a paradigm shift in the UN Peacekeeping operation.

\section{Introduction}

This work deals with the changing paradigm of UN peacekeeping in the post cold war era. Can a self sustaining and lasting peace be constructed in societies torn apart by war or gross violations of human rights? This has been one of the pressing issues faced by the UN since the end of the cold war. The UN has engaged in efforts to step up operations involving intra-state conflicts in Cambodia, Somalia, Angola, Haiti and the former Yugoslavia. However, while traditional UN peacekeeping missions were designed to keep the peace between states, the management of intra-state conflicts required keeping the peace within states.

Thus the UN began to develop a new pattern of peace support activities and tasks designed to respond to the challenges of intra-state conflicts, consolidating civil order and establishing the political and socio-econolic conditions for sustainable peace. As a result UN became engaged in building peace in war-torn societies. By the 1990s and its peace operations involved three prinicipal activities: conflict prevention and peace making, peacekeeping and peacebuilding.Thus UN peacekeeping came to be recognised as a wider form of peacekeeping or second generation peacekeeping.

A major guideline to boost up this concept was found in the work of UN Secretary General Boutros Boutros Ghali's work captioned "An Agenda for Peace". Peacekeeping has been defined as the deployment of a United Nations presence in the field, hitherto with the consent of all the parties concerned, normally involving United Nations military and Ior police personnel and frequently civilians as well. Besides this, it also gives a clear exposition of three other conceptspeacemaking, preventive diplomacy and peacebuilding.Ghali defines peacemaking as activities designed to bring hostile parties together by peaceful means. Peacebuilding is defined as activities to build peace after a conflict in order to avoid its recurrence.(Ghali,1992)

The 'Agenda for Peace' was however relatively limited in scope and content. Besides, the root causes that need to be resolved in the prevention of conflicts are not adressed in the Agenda. The significance of economic despair, social justice and political oppression as causes of armed conflict are not discussedat all. The UN was hesitant to adress these issues for fear of being accused of interfering in the internal affairs of member states. Despite these lacunaes, the Agenda for Peace became a pivotal instrument for the UN's fairly activist role during Ghali's tenure as Secretary General though with a number of setbacks. In 1995, a supplement to "An Agenda for Peace" was published by Boutros Ghali. It has used the term "peace-building" to refer to both pre and post conflict measures. Like "An Agenda For Peace", 
the supplement has focused overwhelmingly on preventive diplomacy on the one hand and post conflict peace-building on the other. The long- term prevention mission was described as "the creation of structures for the institutionalization of peace". It has also introduced a concept of "preventive peace-building" or "structural prevention" which addresses the basic causes of armed conflict. It is a comprehensive strategy integrated preventive measures of peace-building with preventive diplomacy and post conflict peace-building policies.

\section{Operationalization of the New Paradigm of UN Peacekeeping}

The priniciples of the Agenda for Peace found its first successful application in the UN mission of Mozambique in December 1992 where its mandate clearly shows the amalgation of the principles of peacebuilding along with peacemaking.

Let us closely look at its mandate. It indicates as follows:

1. To monitor the ceasefire, verify the separation and concentration of forces, their demobilisation and the collection, storage and destruction of weapons.

2. To monitor and verify the complete withdrawal of foreign forces and to provide security in the transport corridors.

3. To monitor and verify the disbanding of private and irregular armed groups.

4. To authorize security arrangements for vital infrastructures and to provide security for United Nations and other international activities in support of the peace process.

5. To provide technical assistance and monitor the entire electoral process.

6. To coordinate and monitor humanitarian assistance operations, in particular those relating to refugees, internally displaced persons, demobilized military personnel and the affected local population

As highlighted before, the supplement to An agenda for Peace in 1995 has addressed the basic causes of armed conflict. Throughoutr the 1990s, the UN Security Council Resolution records portray the role, peacebuilding has played in UN efforts while reacting to the international crises. The more recent engagement reflecting peacebuilding is the joint UN-African Union Mission in Darfur(UNAMID).

\subsection{Scope of Humanitarian Intervention in Peacekeeping}

Michael Walzerin in his paper "Just and Unjust Wars" suggests that the aim of the intervening army is simply to stop the killing. Its leaders must emphasize that their motives are primarily humanitarian. Intervention by the UN for humanitarian purposes has emerged as a new element in UN peacekeeping after the end of the cold war. Earlier it had been a basic assumption of international law since 1945, as given by Articles 2 (4) and 2(7) of the UN Charter, that the use of force is illegal. Two exceptions to this rule can be in self-defence and collective security. Until the end of the cold war, most international lawyers have agreed that intervention for the purposes of humanitarianism or democracy building could not supersede the existing principles of national sovereignty allowing only for these two exceptions. This is strongly emphasised in the UN Charter's context and purpose-an effort to delegitimise individual acts of war by vesting sole authority for the non-defensive use of force in the Security Council.( Walzer,nd)

There were two reactions to this legal opinion arising out of a debate among international lawyers as to whether the general prohibition on the use of force enshrined in Article 2 (4) should be made more flexible to accommodate other important principles of the U.N. like the promotion and protection of human rights.

The first one was by the 'Restrictionist' lawyers ie. Christine Gray and Simon Chesterman who were opposed to such flexibility in the Article and were reluctant about endorsing the use of force in the name of defending human rights. The second argument was by the 'Counter - Restrictionist' lawyers such as Christopher Greenwood who were in favour of the Charter being made more flexible to accommodate other exceptions besides Article 2 (4) and who supported the use of force to protect human rights. They highlighted on a series of cases from the 1990 s as states' promotion of a new customary rule, with statements by western government's articulating humanitarian motives.

It is now believed that international law is not static and that the intensity and frequency of international behaviour has increased at the rate at which new custom is being generated. The present record of state practice shows a mixed trend. Firstly despite there being no explicit amendment to the U.N. Charter, the realities of post -1990 practice demonstrates support or at least toleration, for Security Council has authorized actions with a clear humanitarian objective. It is found not only through the use of Security Council Resolutions that authorize "the use of all means necessary" to secure humanitarian outcomes but also in the UN endorsements given to those interventions carried out 
by regional coalitions of states.(Buyers \& Chesterman,2003). In the 1990s, enforcement operations have been regarded as legitimate when people are bitterly affected by a proven tyranny of the state's governing authority. So it gives them a moral right to approach the U.N. or other regional organizations for protecting their human rights and improving their lives.

Due to this, most cases of intervention in the post cold war era (with the clear exception of Kosovo) have involved Security Council Resolutions that invoke Chapter VII. While the Charter sanctions unilateral action for the purposes of self defence, the legality of other forms of military action currently rest upon the presence of backing by the Security Council. However, the concept of 'Responsibility to Protect - $\left(R_{2} P\right)$ 'has also emerged to support the expanded scope/interpretation of what humanitarian intervention might entail or imply. This relates to a state's responsibility towards its population and to the international community's responsibility in case a state fails to fulfil its responsibilities. First, it involves an intervention by external actors (preferably the international community through the U.N.) in a state that is unwilling or unable to prevent or stop genocide, massive killings and other massive human rights violations. The increase in intra-state conflicts, the growth of international civil society, the increased recognition of human rights and the growing appreciation of global interconnectivity and the responsibility of governments to their citizens during the 1990s have created a lot of pressure on states to protect the civilians in countries other than their own.

Supporters of $\mathrm{R}_{2} \mathrm{P}$ view it as a method of establishing a normative basis for humanitarian intervention and its consistent application. Detractors argue that by justifying external breaches of state sovereignty, $\mathrm{R}_{2} \mathrm{P}$ encourages foreign aggression by stronger nations. The $\mathrm{R}_{2} \mathrm{P}$ principles were first developed by the International Commission on Intervention and State Sovereignty (I.C.I.S.S), established by the Govt. of Canada in the December 2001. It was also submitted in the report of Secretary General Kofi Annan entitled, "The Responsibility to Protect".

\subsection{Emerging Challenges to humanitarian Intervention}

But a major problem with the concept of humanitarian interventions are the ambiguities present in the concept of genocide, that has been used to justify such interventions. Genocide can be simply defined as the mass destruction of a particular ethnic group through a series of indiscriminate killings of the members of that group.

Raphael Lemkin had defined genocide in 1943 before the U.N. gave its interpretation. According to him, genocide does not necessarily mean the immediate destruction of a nation, except when accomplished by mass killings of all members of a nation. It is intended rather to signify a coordinated plan of different actions aiming at the destruction of essential foundations of the life of national groups, with the aim of annihilating the groups themselves. Article 2 in the Genocide Convention of 9 December, 1948, defines genocide as the "intent to destroy in whole or in part, a national, ethnical, racial or religious (Genocide Convention,1948) Genocide could be practised towards a particular section of people even based on gender. Another vicious form of genocide is female infanticide and foeticide. Such killing of infant daughters finds an burning example in India.( Intersections,2009).

There is a problem with the U.N. definition of genocide which is simply too broad and loose and therefore allows for no qualitative differentiation between situations where truly huge numbers are killed or threatened and where much smaller numbers are killed or threatened. Nor does the definition distinguishes between different (lethal and less lethal) forms of 'ethnic cleansing' which can range from territorial expulsion to mass incarceration to mass murder.

\subsection{Three Major Positions on Humanitarian Interventions}

There are three positions regarding the issue of humanitarian intervention in conflict-ridden areas and whether it is justified to have external military intervention. The first one is the principle scrupulously respecting the sovereignty of all nations ie. the right of national self-determination. This is a vital means of protecting the weaker and newly emerging countries with respect to the more powerful nations. Existing international law in this respect, particularly the U.N. Charter has been formally accepted by allmember- states. It has become a plea for not supporting humanitarian intervention in the form of external military force in order to protect human rights in any nation.

The second view favouring humanitarian intervention is by those who are holding a normative position for humanitarian intervention. They maintain that morality must take a priority over legality and moral considerations demand intervention no matter what is the- internationally recognised legal position

The third view is based on the normative principle of respecting the freedom of peoples. It recognises and respects the fact that we live in a world where different nations are constituted by different peoples. It insists that we must respect the rights of people to overthrow their own tyrants. For instance, only the people of South Africa had the right to 
overthrow the white apartheid regime in South Africa.

Mass expulsion of a people does not qualify as a justification for such an intervention as people retain their agency to struggle for justice even in exile. In the last few decades, there have been three such occasions when the existence of a people was at stake. i) In 1975, East Timor suffered a massacre by the Indonesian troops, determined to hold on to East Timor, though its native population was waging a just struggle for national liberation. One third of the people of East Timor were massacred once the U.S. had given the signal to Indonesia in January, 1975 to invade. ii) Another instance where such an intervention took place was in Rwanda in 1993, when a majority of the Tutsi people were massacred. Neither the U.S. nor any European power had any interest in intervening to prevent this slaughter since Rwanda had no strategic- political value for the west. iii) Finally, there was the Vietnamese invasion of Kampuchea in 1979 to put an end to the Pol Pot regime which eliminated around half of the population of the country by its acts of genocide. Whatever be the strategic reasons or motives behind Vietnamese action, it was definitely wished for.

\subsection{US Domination in UN Peacekeeping}

But the U.S.A. being the sole superpower began to exert a more dominant role in the Security Council's decision making process. So it began to create more obstacles in the peacekeeping process in the post-cold war phase when compared with the cold war period. For example it used its vetoes more frequently in Security Council resolutions and instigated 'peace' missions where its interests were threatened. America has been the greatest financial contributor to the U.N. in its various activities and to its peacekeeping missions.

\section{Modifications in the Peacekeeping System of the U.N. in the Post Cold War Era}

Regarding the performance of the U.N. in keeping peace since its creation during the forty year period from 1948, when the U.N.T.S.O. was despatched, to the Middle East, in January, 1988, as the cold war was winding down the U.N. had deployed thirteen peacekeeping operations. By contrast, during the next sixteen years, till the end of 2003, the UN has launched forty-four peace operations.

There were many factors leading to the sudden increase, but the primary cause was the end to the East - West competition in the Security Council and the constant threat of the veto by members of the $P-5$. While there were some 300 vetoes by Security Council members during the cold war period, since 1991, when the Soviet Union ceased to exist, there have been fewer than ten. The Council has not only overcome its deadlock but its ability to agree on any number of issues has greatly increased.

Many of the recent peacekeeping operations have been undertaken in situations of internal conflict and failed states. These situations would have been very difficult during the Cold War, not only because of territorial spheres of influence but also because the Council was not able to reach a consensus on a system for re-building a society emerging from instability. It was impossible for the world body to out rightly support a democratic ideology based on private enterprise and capitalism or even a Communist ideology with a centrally planned economy. The end of the cold war implied that a number of civil wars happening in Kampuchea, El Salvador and Mozambique or the freedom struggle in Namibia were available for mediated solutions.

\subsection{Conflict Prevention as An Emerging Peace Instrument In The Post Cold War Era}

Prevention of conflicts has also been a salient feature in the expansion of the peacekeeping mechanism of the U.N. in the post cold war era. "Preventive Deployment" of troops, peacemaking and preventive diplomacy have been referred to by Boutros Ghali in his "An Agenda for Peace." In this context, the gap between the early recognition of a crisis (early warning) and an early action to prevent it has been a major deficiency in the U.N.'s handling of crisis situations.

Two classic instances where this gap was found are in the case of genocide in Rwanda and Kosovo, which have been discussed as follows -

i. In the case of Rwanda, there was plenty of early warning. Operation Turquoise look place only after 800,000 people had already been slaughtered, inspite of the presence of a U.N. Blue Helmet mission (U.N.A.M.I.R.). The U.N. chose not to authorize the strengthening of the Blue Helmet force or the force commander's request to take preventive measures, and instead reduced the force when the violence began. According to U.N. estimates, a deployment of around 5,000 soldiers in April, 1994 would have been sufficient to check the countless human tragedies. 
ii. In the case of Kosovo, there was a lack of a common strategy. So it took nearly a decade after the suspension of Kosovo's autonomy for the international community to decide on military intervention. Kosovo was generally sidelined in the peace discussions at the Balkans because it was clear that the parties would never agree over it. N.A.T.O.'s military action in April 1999 was not a preventive effort, but strategically motivated (U.S. expressing its continuing authority in Europe) as well as a reaction to a humanitarian dilemma that had been giving off warning signals for some time. The early recognition of conflict by the experts never led to appropriate political measures.(Bernhard \&Varvik,n.d,p.120)

\subsection{Concept of Peace Enforcement in the Post Cold War Era}

The debate on the legality of humanitarian intervention assumed a greater significance in the 1990's. The instrument which has some times been used by the U.N. to conduct this is the use of force. There is a general restriction on the use of force in the U.N. charter found in Article 2 (4), where according to the dominant legal opinion, the application of Article 2 (4) refers to the use of military force between states. This however does not prohibit the use of force in a general sense. Some exceptions to their abolition are in case of:-

a. Collective Measures against a disturber of peace on basis of chapter VII.

b. The right of self - defence against an armed attack according to Article 51

c. Measures taken against former 'enemy states' according to Articles 53 and 107(Gareis \& Varvick,2005,pp.6769).

A 'Declaration of Principles' by the General Assembly has a telling influence in this regard. It considers the abolition on the use of force to be the underlying principle of state behaviour. These comprise the following:-

i) Aggressive wars are branded as crimes against peace.ii) States may not use or threaten the use of force in order to harm the existing status of international borders and may not make use of a propaganda of aggression.iii) They may not use force in measures of retaliation iv) They may not involve themselves in the formation or support the formation of irregular armed forces or armed bands which have as their purpose, the violation of the sovereign territory of other states. v) They must refrain from the organization, incitement on support of acts of civil war or terrorism in another state, and may not suffer the support of such actions to take place in their sovereign territory. vi) They may not obtain the sovereign territory of another state through the use of force.(GAOR 2625,1970)

\section{Conclusion: Status of Humanitarian Interventions in the Post Cold War Era}

The 1990s witnessed a series of military actions for enforcing peace ostensibly supported by a humanitarian objective. This rationale boosted the concept of humanitarian intervention on the following grounds:

1. The U.N. Mission in Somalia (1992) was the first instance of humanitarian intervention implying that force was used solely for providing humanitarian relief to the people affected by civil war in Somalia.

2. The need for humanitarian intervention was very urgently and desperately needed in Rwanda in 1994 which became one of the most burning example of genocide in the $20^{\text {th }}$ century. It could not be prevented in time by the UN as about 1 million innocent civilians were massacred within a period of $3-4$ months in the name of national interest and in violation of the established rules of international law.(Gareis \& Varvick,2005,p.48)

The fundamental argument in favour of humanitarian intervention is that the principles of sovereignty and non intervention cannot be sacrosanct in the face of massive human suffering caused by either the collapse of a state into civil war and anarchy or a government's behaviour towards its people. But there remain, of course, serious differences about the legitimacy of external military interventions in specific political contexts. Not being sacrosanct is not the same as saying there is automatic justification for such intervention.

Though the humanitarian imperative is not yet a self established norm, it is much more widely accepted now. This was evident in the declaration of September 2005, U.N. Summit which said that "Each individual state has the responsibility of protecting its population from genocide, war crimes, ethnic cleansing and crimes against humanity."(GAOR.60 in Lanhametc.,1998). As quoted by Michael Ignatieff, while gripped with man-made humanitarian calamities, the Council may well find itself trapped between cross - pressures from people and governments. The former, influenced by media accounts of gross violations of human rights and ethnic cleansing are likely to press for quick and decisive action.(Ignatieff in Lanham,ed.,1998). Member States, on the others side, reluctant to pay the costs and take the risk of intervention, may be all too ready to delegate the tasks to the Security Council or to regional organizations. Hence, they have been known to quietly discourage forceful Council action in places like Rwanda, Srebrenica and Darfur, as a 
very recent case. This is quite evident in Kofi Annan's "In Larger Freedom Report" which highlights that "nowhere is the gap between rhetoric and reality - between declarations and deeds - so stark and so deadly as in the field of international humanitarian law". (Annan,2005) With the passage of time, the Council's interest in humanitarian goals has certainly grown, even if its willingness to act quickly has developed at a slower rate. Moreover, the Council has never had a monopoly on inconsistent and manipulated decision making. For example, while there are few constitutional restrictions on the Council's freedom to choose and decide, the extent to which other states and actors obey the Council's decisions, or respect its political and legal authority, varies from case to case and resolution to resolution. In these cases, the service, though actively done has a political angle, tilting towards powerful nations, rather than pursuing in a principled and impartial manner a humanitarian cause for the people in distress.

\section{References:}

Boutros B Ghali; An Agenda for Peace: preventive diplomacy, peacemaking and peacekeeping;United Nations,(New York: 1992); para. 23

UN SCR 797, 16 Dec. 1992 in Michael Walzer; "The arguement about Humanitarian intervention", polylog web article, p.24

Michael Byers and Simon Chesterman, "Changing the Rules about Rules? Unilateral Humanitarian Intervention and the Future of International Law" in Humanitarian Intervention: Ethical, Legal and Political Dilemmas eds. J.L. Holzgrefe and Robert Keohane, Cambridge University Press; (Cambridge, 2003); p. 178 - 179

Robert Jackson, The Global Covenant Human Conduct in A World of States, (Oxford University Press, (Oxford: 2000); Mariano Aguire; "Humanitarian Intervention and U.S. Hegemony: A Re-conceptualization" in AchinVanaik ed. Masks of Empire; Tulika Press; (New Delhi: 2007); p. 170.

Raphael Lemkin, Axis Rule in Occupied Europe Analysis of Government:Laws of Occupation-Analysis of Government-Proposals for redress, Chapter 9 (Washington D.C: Carnegie Endowment for International Peace,1944), Chapter 9, pp.79-95.

Genocide Convention, The United Nations, 9 December 1948

Felix Gross, World politics and Tension areas; New York university Press; (New York:1966)

http://intersections.anu.edu.au/; Intersections: Gender and Sexuality in Asia and the Pacific Issue 22, October 2009. Innervoice ofbharath.wordpress.com

Bernhard and Varvick, p. 120

Gareis and Varvick; The United Nations: An Introduction; Palgrave MacMillan, (New York: 2005) ibid, pp. 67, 68 - 69.

GAOR 2625 (XXV), "Declaration on Friendly Relations; dt. 24th October, 1970.

Gareis and Varwick, p. 21; Para 2. . Kofi Annan, In Larger Freedom: Towards Development, Security and Human Rights for All; (New York: United Nations, 2005), p. 48, para-134.

1G.A.O.R. 60 / L.1, Para.138

Michael Ignatieff, The Stories We Tell: Televisions and Humanitarian Aid, in Hard Choice: Moral Dilemmas in Humanitarian Intervention, (Lanham MD: Rowman and Littlefield, 1998); pp. 287-302

Michael Ignatieff, The Stories We Tell: Televisions and Humanitarian Aid, in Hard Choice: Moral Dilemmas in Humanitarian Intervention, (Lanham MD: Rowman and Littlefield, 1998); pp. 287-302

Kofi Annan, In Larger Freedom: Towards Development, Security and Human Rights for All; (New York: United Nations, 2005), p. 48, para-134.

${ }^{1}$ Kissinger Henry, (1999) "Diplomacia”, Tiranë: Laert Editor, pp. 81 